\title{
nature
}

\section{How to live with cheap oil}

The much-reduced price of oil must be an economic benefit in oil-consuming economies, but it is not too soon to begin preparing for the next price rise.

THE troubles caused by the declining price of oil continue, which must be the only satisfaction the impoverished oil producers derive from their inability to make the cartel called OPEC (for Organization of Petroleum Exporting Countries) effective. In Britain, the spot market for crude oil is in chaos, as traders have sought to back away from contracts signed when prices of $\$ 15$ per barrel seemed a very long way off. In France as well as Britain, the nationalized coal-producing industries are having to reduce their prices to remain competitive, with the result that they will be asking the governments that keep them going for larger subsidies. In India, the prime minister is in trouble for having put up the price of gasoline when everybody expects prices to be falling.

In both Britain and the United States, the falling price of oil has implications for taxation policy. The British government is saying that reduced revenues from North Sea oil will prevent it from reducing personal taxes in next month's budget (but that may be a blind). In the United States, falling prices for oil imports (now roughly a third of total consumption) have brought back into fashion the notion of an import levy (called a "fee" so that nobody should think the administration is increasing taxes). The domestic producers would welcome the protection, while the government cannot be indifferent to a scheme that might trim the federal deficit by as much as 10 per cent. But some countries dependent on oil revenues, Mexico in particular, will need financial help of a kind not now in prospect.

Where will all this turmoil end? The surprise is the speed with which the price of oil has fallen. At the time of OPEC's last formal meeting in December, when Saudi Arabia made it plain that it would not thereafter stint on oil production, the price was certain to fall below $\$ 25$ per barrel, but $\$ 15$ appeared beyond the bounds of possibility (see Nature 319, 2; 1986). Yet the slump should not have been the bombshell that it is. Over periods of time measured in months, the demand for oil and its products is inflexible. If the supply should suddenly increase, as it may have done to the tune of more than the equivalent of the 100 million tonnes produced each year in the North Sea, the oil producers are bound to be in a fix. Those with oil costing more to lift out of the ground than the going market rate will of course shut down their production wells, but others will have an incentive to keep on producing to generate the cash to amortize the capital cost of their facilities, almost always a larger component than the mere cost of recovery in the ultimate price. So, in the short run, the lower bound to the price of oil will be that at which enough producers with high recovery costs go out of business to balance the increased supply. Even in high-cost regions such as Alaska and the North Sea, there is probably some way to go before that point is reached.

\section{Oscillation}

Long before then, other forces will tend to stiffen the price of oil. Low-cost producers become high-cost producers when their wells begin to run dry, making secondary recovery necessary. And although it is unlikely that people will drive their motor cars further or more furiously simply because the price of gasoline has fallen, the industrial users of energy who have been switching from oil to coal in the past few years will begin to switch back again. On a similar timescale, the oil producers will go slowly in the development of known resources, and will cut back on the exploration for new fields. Much of that is happening already.

Meanwhile, at any point, Saudi Arabia will be able to change the rules by which other oil producers must live simply by adjusting the output from its unique resource, the world's largest known reserve of cheap petroleum, destined to outlast any other comparable reserve at any imaginable production rate. There can be no complaint if Saudi Arabia chooses to follow such a strategy, but the consequences would be a cyclical fluctuation of the price, which may be less comfortable for the oil consumers than a high but stable price.

How should the oil-consumers prepare for such a strategy? One of the most striking features of the past decade of high oil prices is the way in which industrial economies have been compelled to be more economical in the use of energy. In the United States, for example, where Gross Domestic Product has increased by nearly a third since the first sharp price increases in 1973 , oil consumption has actually fallen by roughly 10 per cent. In Western Europe, always more economical in the use of energy (by the yardstick of production), much the same has happened. If low prices had come to stay, it would make sense that part of the benefit should accrue to oil consumers in the generally reduced cost of relatively inefficient equipment. But since the price of oil may fluctuate on timescales measured in months, while decisions made now about energy-using plant will exert their influence in energy efficiency on timescales measured in decades, there is a strategic case that industrial economies should bias their systems to preserve some of the economic adaptations forced on them in the past decade.

But even the efficient use of energy entails an economic cost, that represented by the usually greater cost of relatively efficient equipment. If industrial economies were to follow the strategy of pretending that the cost of oil is still, say, $\$ 25$ a barrel, which might be done by sufficiently great import levies, people buying equipment would make the same decisions this year as last, but the governments concerned would have much increased revenues that might then be distributed by means of reduced taxes to individual oil consumers. The new benefit to the economies concerned would then be measured by the difference between the tax forgone and the continued extra cost of energy-efficient equipment. There would be some immediate economic benefit, but less than if the fall in the price of oil were fully reflected in domestic prices. As it happens, the proposed levy on oil imports into the United States would be a step along that road, but one whose size ( $\$ 8$ a barrel is talked about) appears to be entirely arbitrary, or at best determined by the price that will keep domestic producers happy.

Other industrial economies are less well placed than the United States, locked as they are into competition with each other and even more eager that the falling price of oil should be made to signal the end of the long recession. Even without an international agreement on oil price strategy, there is much to be said for policies like that proposed for the United States (provided the levy is redistributed as reduced tax). 